\title{
Serum levels of zinc in children with recurrent infections from Lodz Province
} Ocena surowiczego stężenia cynku u często chorujących dzieci z regionu łódzkiego

\author{
1 Department of Paediatrics and Allergy, Korczak Paediatric Centre, Copernicus Memorial Hospital in Lodz, Medical University of Lodz, Łódź, Poland \\ ${ }^{2}$ Synevo Laboratory, Copernicus Memorial Hospital in Lodz, Łódź, Poland \\ Correspondence: Professor Iwona Stelmach, MD, PhD, Department of Paediatrics and Allergy, Korczak Paediatric Centre, Copernicus Memorial Hospital in Lodz, Medical University of Lodz, \\ Piłsudskiego 71, 90-329 Łódź, Poland, tel.: +48 4220747 26, fax: +48 4267763 58, e-mail: alergol@kopernik.lodz.pl
}

\begin{abstract}
Infections, especially those of the respiratory system, are very common in children from areas with high air pollution, and the incidence of infections is even greater in the case of immature immune system. Zinc plays an important role in the regulation of innate and acquired immune response. This element is involved in the production of proteins, wound healing, DNA synthesis and cell division, and is essential in the development and activation of $\mathrm{T}$ cells. Zinc deficiency disrupts phagocytosis, intracellular killing and cytokine production by macrophages. The aim of the study was to assess serum zinc levels in children with recurrent respiratory infections from the Łódź region, diagnosed at the Department of Paediatrics and Allergy in Korczak Paediatric Centre. Materials and methods: The study included 60 children with recurrent infections ( $\geq 6$ respiratory infections over 6 months) and 60 healthy children aged 1-18 years. Flame spectrometry was used to measure serum zinc levels in all patients. Results: Nearly $40 \%$ of children with recurrent infections had low serum zinc levels $(<70 \mu \mathrm{g} / \mathrm{dL})$. There were no statistically significant differences in zinc levels depending on sex. Multivariate analysis showed significant differences in serum zinc levels between the control group and the group with recurrent respiratory infections $(p=0.044)$. Conclusions: The obtained results indicate that zinc deficiency is frequent in children with recurrent respiratory infections from the region of Łódź.
\end{abstract}

Keywords: zinc, children, infection

Streszczenie Infekcje, szczególnie układu oddechowego, występują bardzo często u dzieci z terenów o wysokim współczynniku zanieczyszczenia powietrza, a przy niedojrzałym układzie odpornościowym częstość zakażeń jest jeszcze większa. Cynk pełni ważną funkcję w procesach regulacji wrodzonej i nabytej odpowiedzi immunologicznej. Pierwiastek ten bierze udział w produkcji białek, gojeniu ran, syntezie DNA i podziałach komórkowych oraz jest niezbędny w procesie rozwoju i aktywacji limfocytów T. Niedobór cynku zaburza fagocytozę, zabijanie wewnątrzkomórkowe oraz produkcję cytokin przez makrofagi. Celem pracy była ocena surowiczego stężenia cynku u często chorujących dzieci z regionu łódzkiego, diagnozowanych na Oddziale Klinicznym Interny Dziecięcej i Alergologii Ośrodka Pediatrycznego im. J. Korczaka. Materiał i metoda: W badaniu wzięło udział 60 dzieci często chorujących ( $\geq 6$ infekcji układu oddechowego/6 miesięcy) oraz 60 dzieci zdrowych w wieku 1-18 lat. U wszystkich pacjentów oznaczono surowicze stężenie cynku metodą spektrometrii płomieniowej. Wyniki: U blisko $40 \%$ dzieci z nawracającymi infekcjami stwierdzono niskie surowicze stężenia cynku $(<70 \mu \mathrm{g} / \mathrm{dl})$. Nie odnotowano statystycznie istotnych różnic w stężeniu badanego pierwiastka w zależności od płci. W analizie wieloczynnikowej wykazano istotne różnice w surowiczym stężeniu cynku między grupą kontrolną a grupą z nawracającymi infekcjami dróg oddechowych ( $p=0,044)$. Wnioski: Uzyskane wyniki wskazują, że niedobór cynku jest częsty u dzieci z nawracającymi infekcjami układu oddechowego $\mathrm{z}$ regionu łódzkiego.

Słowa kluczowe: cynk, dzieci, infekcja 


\section{INTRODUCTION}

$\mathrm{I}$ nfections, especially those of the respiratory system, are very common in children with immature immune system who are at a high risk of exposure to air pollution. This particular sensitivity to infections is associated with the immaturity of mechanisms responsible for both nonspecific and specific immunity ${ }^{(1)}$. The mean number of respiratory infections in children is 6-8 incidents annually, and is significantly higher in children attending nurseries and kindergartens ${ }^{(2)}$.

Zinc is a trace element known to be essential for many cellular metabolic processes and catalytic activity of over 100 enzymes in humans. It is involved in the immune functions, protein synthesis, wound healing, DNA synthesis and cellular divisions. Its immunomodulatory and anti-inflammatory effects have been assessed in many studies. Zinc deficiency impairs innate and acquired immune response, phagocytosis, intracellular killing and cytokine production by macrophages. Even mild zinc deficiency can impair macrophage and neutrophil function ${ }^{(3-9)}$. This element is also essential for the development and activation of $\mathrm{T}$ cells. Zinc deficiency has been demonstrated to cause Th1/Th2 functional imbalance and reduce interferon $\gamma(\mathrm{INF}-\gamma)$, interleukin 2 (IL-2) and tumour necrosis factor $\alpha$ (TNF- $\alpha$ ) production $^{(10-12)}$.

\section{AIM}

The aim of the study was to assess serum zinc levels in children from the Łódź region who often develop recurrent respiratory infections, diagnosed at the Department of Paediatrics and Allergy in Korczak Paediatric Centre.

\section{MATERIALS AND METHODS}

A total of 60 children with recurrent infections and 60 healthy children (control group) aged between 1 and 18 years, who were diagnosed in the Department of Paediatrics and Allergy between October 1, 2016 and
November 1, 2018, were included in the study. Recurrent infections were defined as 6 or more episodes of respiratory infection within 6 months. The study was conducted after obtaining a written consent of parents/ legal guardians and patients. Children with known chronic diseases, including metabolic diseases, which could affect the results of the study, were excluded. We measured serum zinc levels with flame spectrometry using Atomic Absorption Spectrometer PinAAcle 900T (PerkinElmer).

The study was approved by the Bioethics Committee at the Medical University of Lodz (No. RNN/241/17/KE, dated July 11, 2017).

\section{Statistical analysis}

Data were presented in the form of absolute numbers and percentages (\%). Numerical features were described using measures of position - mean $(M)$, median $(M e)$, lower quartile (Q1), upper quartile (Q3); measures of dispersion - interquartile range (IQR), standard deviation (SD), standard error (SE), 95\% confidence interval (CI), and minimum and maximum value of the investigated variable. We used logistic regression and multivariate analysis of variance (ANOVA) without repetitions. The normality of the variable distribution was verified with the $W$ Shapiro-Wilk test, while Levene's test was used to verify the homogeneity of variance. Statistical significance threshold was set at $p=0.05$. Stata $\% /$ Special Edition, version 14.2 (StataCorp LP, College Station, Texas, USA) was used for the analysis.

\section{RESULTS}

Mean serum zinc level in the patients was $77.97 \mu \mathrm{g} / \mathrm{dL}$ $( \pm S D=15.41 \mu \mathrm{g} / \mathrm{dL})$. There were no statistically significant differences in serum zinc levels depending on sex ( $p=0.082)$ or between the study groups $(p=0.183)$. Mean serum zinc level was $75.35 \mu \mathrm{g} / \mathrm{dL}( \pm S D=16.11 \mu \mathrm{g} / \mathrm{dL})$ in girls and $80.34 \mu \mathrm{g} / \mathrm{dL}( \pm S D=14.47 \mu \mathrm{g} / \mathrm{dL})$ in boys. Mean serum zinc level was $80.01 \mu \mathrm{g} / \mathrm{dL}( \pm S D=16.32 \mu \mathrm{g} / \mathrm{dL})$ in

\begin{tabular}{|c|c|c|c|c|c|c|c|c|}
\hline \multirow{2}{*}{ Group } & \multirow{2}{*}{ Sex } & \multicolumn{7}{|c|}{ Statistical parameter } \\
\hline & & $M$ & Me & $Q_{1}-Q_{3}(I Q R)$ & SD & SE & $95 \% \mathrm{Cl}$ & Min-max \\
\hline \multirow{3}{*}{ Recurrent infections $(n=60)$} & Girls & 74.15 & 73.50 & $63.30-85.30(22.00)$ & 15.97 & 2.97 & $68.07-80.22$ & $38.40-102.20$ \\
\hline & Boys & 77.60 & 78.90 & $65.70-87.40(21.70)$ & 12.57 & 2.26 & $72.99-82.21$ & $54.70-97.10$ \\
\hline & Total & 75.93 & 76.85 & $64.90-86.55(21.65)$ & 14.30 & 1.85 & $72.24-79.63$ & $38.40-102.20$ \\
\hline \multirow{3}{*}{ Controls $(n=60)$} & Girls & 76.60 & 77.00 & $63.90-88.60(24.70)$ & 16.45 & 3.11 & $70.22-82.98$ & $49.20-115.60$ \\
\hline & Boys & 83.00 & 82.60 & $75.95-92.50(16.55)$ & 15.85 & 2.80 & $77.28-88.71$ & $40.00-120.20$ \\
\hline & Total & 80.01 & 81.60 & $72.90-91.10(18.20)$ & 16.32 & 2.11 & $75.80-84.23$ & $40.00-120.20$ \\
\hline \multirow{3}{*}{ Total $(n=120)$} & Girls & 75.35 & 74.40 & $63.30-87.80(24.50)$ & 16.11 & 2.13 & $71.08-79.63$ & $38.40-115.60$ \\
\hline & Boys & 80.34 & 82.30 & $69.10-92.10(23.00)$ & 14.47 & 1.82 & $76.70-83.99$ & $40.00-120.20$ \\
\hline & Total & 77.97 & 79.55 & $66.10-90.05(23.95)$ & 15.41 & 1.41 & $75.19-80.76$ & $38.40-120.20$ \\
\hline
\end{tabular}

Tab. 1. Descriptive statistics for serum zinc levels $[\mu \mathrm{g} / \mathrm{dL}]$ in study groups $(\mathrm{p}=0.183)$ and by sex $(\mathrm{p}=0.082)$ 


\begin{tabular}{|c|c|c|c|c|c|c|c|c|}
\hline \multirow{2}{*}{ Group } & \multirow{2}{*}{$\begin{array}{l}\text { Age group } \\
\text { [years] }\end{array}$} & \multicolumn{7}{|c|}{ Statistical parameter } \\
\hline & & $M$ & Me & $Q_{1}-Q_{3}(\mathrm{IQR})$ & SD & SE & $95 \% \mathrm{Cl}$ & Min-max \\
\hline \multirow{3}{*}{ Recurrent infections $(n=60)$} & $0-6$ & 76.56 & 74.55 & $65.65-88.85(13.20)$ & 14.54 & 2.10 & $72.34-80.78$ & $38.40-102.20$ \\
\hline & $7-18$ & 73.42 & 81.05 & $59.70-83.75(24.05)$ & 13.59 & 3.92 & $64.79-82.06$ & $53.80-92.20$ \\
\hline & Total & 75.93 & 76.85 & $64.90-86.55(21.65)$ & 14.30 & 1.85 & $72.24-79.63$ & $38.40-102.20$ \\
\hline \multirow{3}{*}{ Controls $(n=60)$} & $0-6$ & 80.50 & 79.65 & $71.60-94.70(23.10)$ & 18.72 & 3.21 & $73.97-87.03$ & $40.00-120.20$ \\
\hline & $7-18$ & 79.38 & 82.10 & $73.00-90.30(17.30)$ & 12.85 & 2.52 & $74.19-84.56$ & $49.20-94.80$ \\
\hline & Total & 80.01 & 81.60 & $72.90-91.10(18.20)$ & 16.32 & 2.11 & $75.80-84.23$ & $40.00-120.20$ \\
\hline \multirow{3}{*}{ Total $(n=120)$} & $0-6$ & 78.19 & 78.90 & $65.90-90.50(24.60)$ & 16.41 & 1.81 & $74.59-81.80$ & $38.40-120.20$ \\
\hline & $7-18$ & 77.50 & 78.90 & $65.90-90.50(24.60)$ & 13.20 & 2.14 & $73.16-81.84$ & $38.40-120.20$ \\
\hline & Total & 77.97 & 79.55 & $66.10-90.05$ (23.95) & 15.41 & 1.41 & $75.19-80.76$ & $38.40-120.20$ \\
\hline
\end{tabular}

Tab. 2. Descriptive statistics for serum zinc levels $[\mu \mathrm{g} / \mathrm{dL}]$ in study groups $(\mathrm{p}=0.128)$ and by age $(\mathrm{p}=0.520)$

the control group and $75.93 \mu \mathrm{g} / \mathrm{dL}( \pm S D=14.30 \mu \mathrm{g} / \mathrm{dL})$ in the group of patients with recurrent respiratory infections (Tab. 1).

There were no statistically significant differences in serum zinc levels depending on age $(p=0.520)$. Mean serum zinc levels were $78.19 \mu \mathrm{g} / \mathrm{dL}( \pm S D=16.41 \mu \mathrm{g} / \mathrm{dL})$ in the group of 0 -6-year-olds, and $77.50 \mu \mathrm{g} / \mathrm{dL}( \pm S D=13.20 \mu \mathrm{g} / \mathrm{dL})$ in the group of 7-18-year-olds (Tab. 2).

Multivariate analysis including sex and age groups, with a division into groups with reference zinc levels $(\geq 70 \mu \mathrm{g} / \mathrm{dL})$ vs. below normal levels $(<70 \mu \mathrm{g} / \mathrm{dL})$ revealed statistically significant differences between controls and the group with recurrent respiratory infections $(p=0.044)$. Low serum zinc levels were detected in
$21.67 \%$ of controls and $38.33 \%$ of patients with recurrent respiratory infections; serum zinc levels below normal were observed in $31.71 \%$ of $0-6$-year-olds and $26.32 \%$ of 7-18-year-olds (Fig. 1).

\section{DISCUSSION}

The study showed that children with recurrent respiratory infections in the Łódź Province had lower serum zinc levels compared to healthy children. Low serum zinc levels $(<70 \mu \mathrm{g} / \mathrm{dL})$ were detected in nearly $40 \%$ of children with recurrent respiratory infections. This relationship was confirmed in children who often develop infections in many studies $^{(13-15)}$. Children with reduced serum zinc levels were

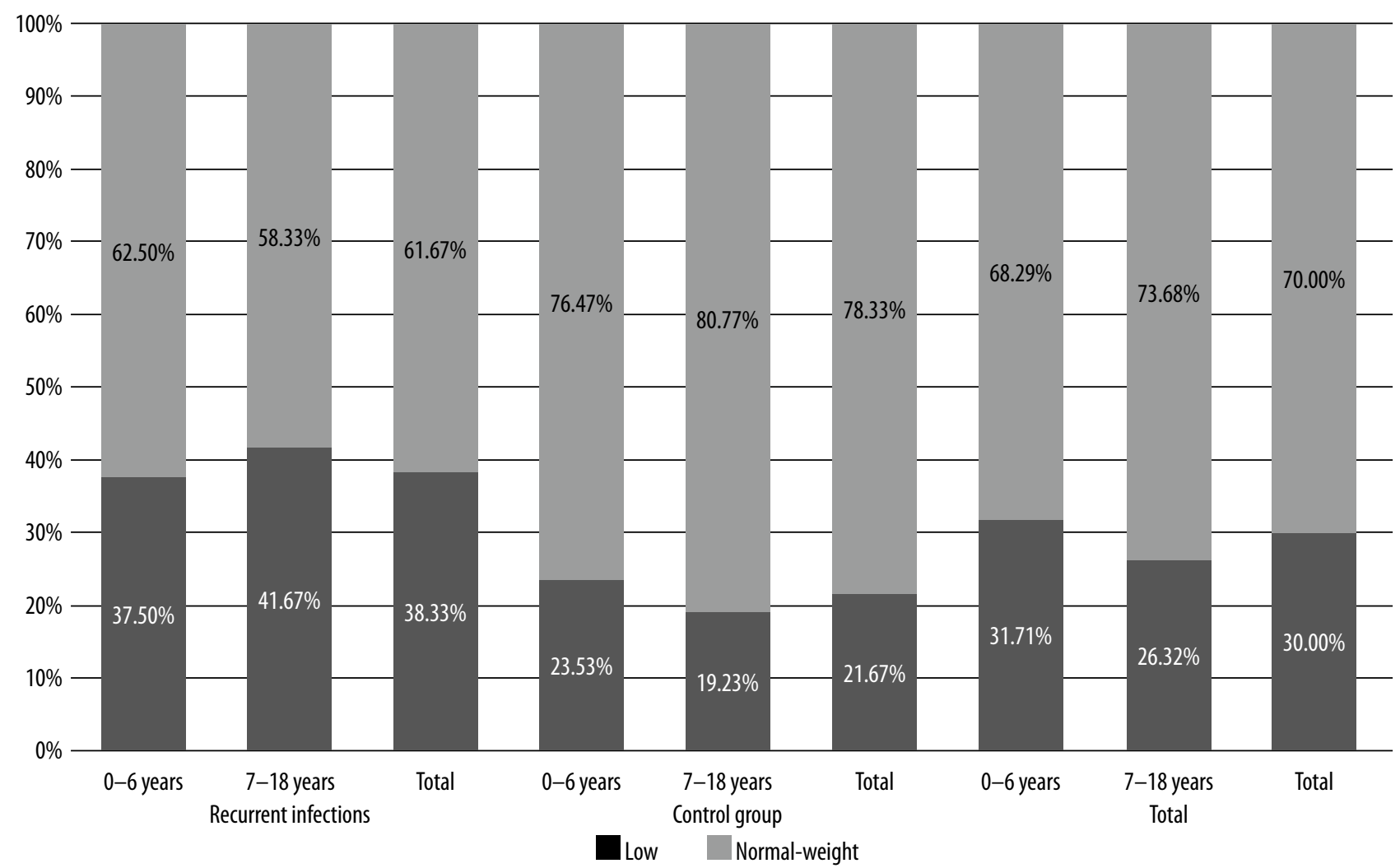

Ryc. 1. The percentage of children in study groups with respect to the reference range of serum zinc levels; differences between controls and the group with recurrent infections: $\mathrm{p}=0.044$, and between age groups: $\mathrm{p}=0.960$ 
almost twice more likely to develop acute upper respiratory tract infections ${ }^{(14)}$. Zinc supplementation may reduce the frequency of lower respiratory infections. A meta-analysis in a group of 5-year-olds showed that zinc supplementation reduced the frequency of respiratory infections, with no impact on their duration ${ }^{(16)}$. Singh and Das showed in their meta-analysis that zinc supplementation for at least 5 months reduced the risk of respiratory infections, absenteeism from school and the need for antibiotic therapy ${ }^{(17)}$. It can be assumed that zinc deficiency reduces the $\mathrm{CD}^{+} \mathrm{CD}^{2} 5 \mathrm{RA}^{+} / \mathrm{CD} 4^{+} \mathrm{CD} 45 \mathrm{RO}^{+}$ratio and the percentage of $\mathrm{CD}^{+} \mathrm{CD}^{+} 3^{+}$cells, which are precursors for cytotoxic $\mathrm{T}$ cells ${ }^{(10-12)}$. An in vitro study showed that zinc inhibits rhinovirus 3C protease, and thus its replication ${ }^{(18)}$. There are also ongoing discussions on the effects of this microelement on rhinovirus binding to a cellular receptor, intercellular adhesion molecule-1 (ICAM-1), or interactions with host's immune response. The results of these studies may help explain the role of zinc deficiency in the pathogenesis of recurrent infections in children.

Since we used a modern method for zinc determination, which shows high and comparable repeatability in the paediatric population as well as low measurement error, it should be assumed that our findings are reliable.

Considering the frequent occurrence of respiratory infections in our patients, a question should be answered whether the observed zinc deficiency may be the cause of recurrent respiratory infections. However, further studies are needed to confirm and thoroughly explain the role of zinc and its deficiency in regulating immune responses.

\section{CONCLUSIONS}

1. Low serum zinc levels $(<70 \mu \mathrm{g} / \mathrm{dL})$ were detected in nearly $40 \%$ of children with recurrent respiratory infections from the Łódź Province.

2. A multivariate analysis showed that reduced serum zinc levels are more common in children from the Łódź Province who often develop respiratory infections compared to healthy children $(p=0.044)$.

\section{Conflict of interest}

The authors do not report any financial or personal connections with other persons or organisations, which might negatively affect the contents of this publication and/or claim authorship rights to this publication.

\section{Funding/Support and role of the sponsor}

The study was supported by the Medical University of Lodz, Poland, grant No. 503/2-056-01/503-21-001-18 and No. 502-03/2-056-01/502-24-381-18.

\section{References}

1. Evans $\mathrm{SE}, \mathrm{Xu} \mathrm{Y}$, Tuvim MJ et al.: Inducible innate resistance of lung epithelium to infection. Annu Rev Physiol 2010; 72: 413-435.

2. Grüber C, Keil T, Kulig M et al.: History of respiratory infections in the first $12 \mathrm{yr}$ among children from a birth cohort. Pediatr Allergy Immunol 2008; 19: 505-512.

3. Hojyo S, Fukada T: Roles of zinc signaling in the immune system. J Immunol Res 2016; 2016: 6762343.

4. Hara T, Takeda TA, Takagishi T et al.: Physiological roles of zinc transporters: molecular and genetic importance in zinc homeostasis. J Physiol Sci 2017; 67: 283-301.

5. Fukada T, Yamasaki S, Nishida K et al.: Zinc homeostasis and signaling in health and diseases: zinc signaling. J Biol Inorg Chem 2011; 16: 1123-1134.

6. Nishida K: [New knowledge from past decade: role of zinc in immune system]. Nihon Eiseigaku Zasshi 2013; 68: 145-152.

7. Wessells KR, Brown KH: Estimating the global prevalence of zinc deficiency: results based on zinc availability in national food supplies and the prevalence of stunting. PLoS One 2012; 7: e50568.

8. Shankar AH, Prasad AS: Zinc and immune function: the biological basis of altered resistance to infection. Am J Clin Nutr 1998; 68: 447S-463S.

9. Hojyo S, Miyai T, Fujishiro H et al.: Zinc transporter SLC39A10/ ZIP10 controls humoral immunity by modulating B-cell receptor signal strength. Proc Natl Acad Sci U S A 2014; 111: 11786-11791.

10. Prasad AS, Beck FW, Bao B et al.: Zinc supplementation decreases incidence of infections in the elderly: effect of zinc on generation of cytokines and oxidative stress. Am J Clin Nutr 2007; 85: 837-844.

11. Prasad AS, Bao B, Beck FW et al.: Zinc enhances the expression of interleukin-2 and interleukin-2 receptors in HUT-78 cells by way of NF-kB activation. J Lab Clin Med 2002; 140: 272-289.

12. Prasad AS: Effects of zinc deficiency on Th1 and Th2 cytokine shifts. J Infect Dis 2000; 182 Suppl 1: S62-S68.

13. Saleh NY, Abo El Fotoh WMM: Low serum zinc level: The relationship with severe pneumonia and survival in critically ill children. Int J Clin Pract 2018; 72: e13211.

14. Ahmed AMS, Ahmed T, Soares Magalhaes RJ et al.: Association between serum vitamin $\mathrm{D}$, retinol and zinc status, and acute respiratory infections in underweight and normal-weight children aged 6-24 months living in an urban slum in Bangladesh. Epidemiol Infect 2016; 144: 3494-3506.

15. Bailey RL, West KP Jr, Black RE: The epidemiology of global micronutrient deficiencies. Ann Nutr Metab 2015; 66 Suppl 2: 22-33.

16. Aggarwal R, Sentz J, Miller MA: Role of zinc administration in prevention of childhood diarrhea and respiratory illnesses: a meta-analysis. Pediatrics 2007; 119: 1120-1130.

17. Singh M, Das RR: Zinc for the common cold. Cochrane Database Syst Rev 2013; (6): CD001364.

18. Turner RB: The treatment of rhinovirus infections: progress and potential. Antiviral Res 2001; 49: 1-14. 